\title{
Zn treatment effects on biological potential of fennel bulbs as affected by in vitro digestion process
}

\author{
Nesrine MAJDOUB ${ }^{1}$, Leila Bettaieb Ben $\mathrm{KAAB}^{1}$, Ana Isabel VIEIRA ${ }^{2}$, Maria Leonor FALEIRO², \\ Soukaina EL-GUENDOUZ ${ }^{3}$, Maria Graça MIGUEL ${ }^{3 *}$
}

\begin{abstract}
Zn treatment effects on the stability of polyphenols, MDA (malondialdehyde) content, antioxidant and lipoxygenase inhibition activities of two varieties of fennel bulbs were studied by using an in vitro gastrointestinal digestion model. Likewise, the effect of $\mathrm{Zn}$ on viability cells of $E$. coli was also performed. The results revealed that high amounts of total phenolic and flavonoid compounds were released during the digestion process, especially after the intestinal phase. Additionally, the antioxidant and lipoxygenase inhibitory activity were affected by the gastrointestinal digestion process and seems to be correlated with total phenol contents. On the other hand, the viability of E. coli was not affected by the activity of our tested bulbs during passage through the artificial digestion model, but the treated bulbs activity contribute relatively to the inhibition growth of bacteria. The survival of $E$. coli in fennel bulbs was challenged with simulated gastrointestinal fluids and the results showed that the E. coli strains, despite having experienced a viability reduction at the intestinal phase, were able to overcome the exposure to the gastrointestinal synthetic fluids. This E. coli ability reinforces the need for good hygienic measures to assure safe fresh produce, even for those that are rich in antibacterial compounds.
\end{abstract}

Keywords: Foeniculum vulgare; Escherichia coli; antioxidant activity; anti-inflammatory activity.

Practical Application: The present research intends to clarify the biological properties of bulb fennel that is used in salads, as well as its effectiveness for protecting human consumers against pathogenic microorganisms, such as Escherichia coli, in a simulated gastrointestinal digestion model.

\section{Introduction}

It is generalized that many compounds, such as polyphenols present in food, exert beneficial effects as antioxidants and/or anti-inflammatory agents. However, after ingestion many factors such as temperature, $\mathrm{pH}$, food matrix and the presence of enzymes may influence not only the stability of polyphenolic compounds but also their biological properties (Pinto et al., 2017). Recently, there has been a growing interest on understanding dietary polyphenolic compounds bioaccessibility through the use of the exposure to in vitro digestion models. In vitro simulated gastrointestinal digestion model is a conventional method to assess the biological properties, such as the antioxidant potential of polyphenolics (Murugan et al., 2016).

As an essential element for health, zinc ( $\mathrm{Zn}$ ) represents the second most abundant inorganic micronutrient in the body (Wang et al., 2015). However, $\mathrm{Zn}$ toxicity can be involved in almost all metabolic processes through competition for uptake, inactivation of enzymes and dislocation of essential elements from functional sites (Rout \& Das, 2003). In fact, the amounts of $\mathrm{Zn}$ consumed and its bioavailability can affect its intestinal absorption (Wang et al., 2015). Zn excess affects membrane integrity and permeability and induces oxidative stress via the generation of reactive oxygen species (ROS) which promotes the peroxidation of lipids (Marichali et al., 2016). It has been also reported that $\mathrm{Zn}$ toxicity reduces the survival rate of Escherichia coli, despite the proved role of $\mathrm{Zn}$ for microbes and other cell growth (Babich \& Stotzky, 1978).

Fennel (Foeniculum vulgare cv dulce) is a perennial umbelliferous (Apiaceae) herb native to the Mediterranean areas. It is consumed as a fresh ingredient in many dishes, such as salads and soups. Its consumption is recognized as having several health benefits and therapeutic activities, particularly on digestive disorders, but also as antioxidant, and anti-inflammatory. Such virtues may be attributed to the presence of phytochemicals, such as flavonoids, phenolic acids and polyacetylenes in relatively high amounts (Rawson et al., 2013). The present research aimed to follow the antioxidant activity of two cultivated fennel bulb varieties ('Latina' and 'Doux Florence') either in the absence or presence of $\mathrm{Zn}$ supplementation during an in vitro digestion simulation. At the same time, it was also our goal to evaluate the effects of digested fennel bulb cultivated in the presence of $\mathrm{Zn}$ on the survival of $E$. coli during the exposure to a simulated gastrointestinal digestion model to elucidate about the potential protection action for human consumers. 


\section{Materials and methods}

\subsection{Chemicals}

All chemicals and reagents were purchased from Sigma-Aldrich (St. Louis, MO, USA) excepting Tris- $\mathrm{HCl}$ and hydrochloric acid $(\mathrm{HCl})$ which were purchased from Merck, Darmstadt, Germany. $\mathrm{Na}_{2} \mathrm{CO}_{3}$ were purchased from Riedel de Haen (Seelze, Germany), Riedel-de-Haen Laboratory chemicals, Germany. Calcium chloride, Folin-Ciocalteu's phenol reagents were purchased from Panreac Quımica, Montcada Reixac, Barcelona, Spain. Potassium dihydrogen phosphate $\left(\mathrm{KH}_{2} \mathrm{PO}_{4}\right)$ and sodium dihydrogen phosphate $\left(\mathrm{NaH}_{2} \mathrm{PO}_{4}\right)$ were purchased from VWR (Leuven, Belgium). Quercetin was purchased from Fluka Biochemika (Sigma-Aldrich,Steinheim, Germany). All chemicals were of the highest purity available.

\subsection{Plant material treatment}

The experiment was conducted in a greenhouse in the plane area of North of Tunisia (EL Alia, Bizerte, Latitude: $37^{\circ} 10^{\prime} 08^{\prime \prime} \mathrm{N}$; Longitude: $10^{\circ} 02^{\prime} 00^{\prime \prime} \mathrm{E}$; Elevation above sea level: $102 \mathrm{~m}$ )), filled with a loamy sand soil, naturally lit with sunlight, with a temperature range of $20-30{ }^{\circ} \mathrm{C}$ and a relative humidity range of $50-80 \%$. Two cultivars of sweet fennel plants: "Latina" (BL) and "Doux de Florence" (BDF) were cultivated according to the recommended technology reported by Senatore et al. (2013). The experimental design was a randomized blocks containing two plants (control and treated with $\mathrm{Zn}$ ) of each variety arranged in individual pots ( $26 \mathrm{~cm}$ upper diameter, $18 \mathrm{~cm}$ lower diameter, $25 \mathrm{~cm}$ in height) of $10 \mathrm{~L}$ volume, filled with the same soil. $\mathrm{Zn}$ treatment was performed by applying $2 \mathrm{mM} \mathrm{ZnSO} \cdot 7 \mathrm{H}_{2} \mathrm{O}$ solution in plants during 75 days with renewing this solution every 5 days. Same conditions were applied to control samples ( $0 \mathrm{mM} \mathrm{Zn)}$ only with adding distilled water. The collected bulbs of each treatment were used for further analysis.

\subsection{Total phenol and flavonoid content}

The total phenolic content (TPC) was determined according to the method of Pavan et al. (2014) with minor modification. In brief, $25 \mu \mathrm{L}$ of digested bulb solution was mixed with $150 \mu \mathrm{L}$ Folin-Ciocalteu reagent, followed by the addition of $100 \mu \mathrm{L}$ sodium carbonate solution. After incubation of $2 \mathrm{~h}$ at room temperature, the absorbance of the reaction mixture was read at $765 \mathrm{~nm}$. Gallic acid was used as standard for calibration curve. TPC was expressed as mg Gallic Acid Equivalents (GAE) per $\mathrm{mL}(\mathrm{GAE} / \mathrm{mL})$. The flavonoid content of the samples was determined by following the method of Pavan et al. (2014) with slight modification. Flavonoid amounts were measured at $510 \mathrm{~nm}$ and the results were expressed in Quercetin Equivalents (QE) per $\mathrm{mL}(\mathrm{QE} / \mathrm{mL})$.

\subsection{Antioxidant and anti-inflammatory activities}

The antioxidant activity of fennel bulb was determined by ABTS radical cation [2,2'-azino-bis(3-ethylbenzothiazoline-6sulphonic acid)] scavenging assay as described by Wang et al. (2015). An ABTS ${ }^{\bullet+}$ stock solution was diluted with ethanol $70 \%$ to achieve an absorbance of $0.70 \pm 0.02$, at $734 \mathrm{~nm}$. Then $20 \mu \mathrm{L}$ of sample were added to the solution of ABTS, for $2 \mathrm{~min}$, at $734 \mathrm{~nm}$, and the percentage of decolourisation was calculated as follows: $\%=\left[\left(\mathrm{A}_{0}-\mathrm{A}_{1}\right) / \mathrm{A}_{0}\right] \times 100$, where $\mathrm{A}_{0}$ was the absorbance of the control (without sample) and $A_{1}$ was the absorbance of the sample.

The lipid peroxidation prevention was determined by measuring the amount of malondialdehyde (MDA) as described by Chowdhury et al. (2017). Simply, digested bulb solution was homogenized in $0.1 \%(\mathrm{w} / \mathrm{v})$ trichloroacetic acid (TCA) and centrifuged $10000 \mathrm{rpm}$ at $4{ }^{\circ} \mathrm{C}$, for $5 \mathrm{~min}$, followed by mixing $200 \mu \mathrm{L}$ of the supernatant with $2.0 \mathrm{~mL}$ thiobarbituric acid (TBA) $(0.5 \%)$ and $30 \mu \mathrm{L}$ of $50 \mathrm{mM}$ butylated hydroxytoluene (BHT). The reaction mixture was incubated for $30 \mathrm{~min}$, at $95^{\circ} \mathrm{C}$. After cooling, it was centrifuged at $10000 \mathrm{rpm}$ at $4{ }^{\circ} \mathrm{C}$, for $15 \mathrm{~min}$, and the absorbance of the supernatant was measured at $532 \mathrm{~nm}$. The measurements were corrected for non-specific absorbance by subtracting the absorbance at $600 \mathrm{~nm}$. The amount of MDA was calculated by using an extinction coefficient of $155 \mathrm{mM} / \mathrm{cm}$.

In the lipoxygenase inhibition, the assay was performed to evaluate the anti-inflammatory activity according to the procedure described by El-Guendouz et al. (2016) with minor modifications. The reaction started with the mixture of the sample $10 \mu \mathrm{L}$ and $5 \mu \mathrm{L}$ of the enzyme solution $(0.054 \mathrm{~g} / \mathrm{mL})$ to $937 \mu \mathrm{L}$ borate buffers and $50 \mu \mathrm{L}$ linoleic acid $(0.001 \mathrm{M})$. The conversion of linoleic acid to 13-hydroperoxylinoleic acid was recorded at $234 \mathrm{~nm}$ and compared to the control solution which did not contain the extract. The $\%$ inhibition for different concentrations of the extracts and the $\mathrm{IC}_{50}$ values were calculated by using the following formula: $\%=\left[\left(\mathrm{A}_{0}-\mathrm{A}_{1}\right) / \mathrm{A}_{0}\right] \times 100$ where $A_{0}$ was the absorbance of the control (without sample) and $A_{1}$ was the absorbance of the sample. All assays were carried out in triplicate.

\subsection{Gastrointestinal in vitro digestion}

The in vitro gastrointestinal digestion process was adapted from the one described by Melo et al. (2013). The bacterial cells of three strains of Escherichia coli, strain S2, S3 (isolated from ready to eat salads) and the reference strain DSM 498 were previously recovered from maintenance at $-80{ }^{\circ} \mathrm{C}$ in Trypticase Soy Agar (TSA) (Biokar Diagnostics). The inoculated Petri dishes were incubated at $37^{\circ} \mathrm{C}$ during $24 \mathrm{~h}$. For the assay an isolated colony from each $E$. coli strain was transferred to $10 \mathrm{~mL}$ of Trypticase Soy Broth (TSB) medium (Biokar Diagnostics) and grown under shaking conditions $(120 \mathrm{rpm})$ at $37^{\circ} \mathrm{C}$ overnight. The previously grown $E$. coli cells were transferred to fresh TSB (1:10) and were grown at $37^{\circ} \mathrm{C}$ with agitation $(120 \mathrm{rpm})$ until the $\mathrm{OD}_{600 \mathrm{~nm}}$ reached $0.3-0.4\left(2.0 \times 10^{9} \mathrm{CFU} / \mathrm{mL}\right)$. Ten grams of fennel bulbs were cut in small and similar pieces, which were first disinfected with 200 ppm of bleach, dried in a flow cabinet for $15 \mathrm{~min}$ and thereafter exposed to UV light for $20 \mathrm{~min}$. The fennel bulbs were then inoculated with $1 \mathrm{~mL}$ of the combined bacterial suspension. After drying, the mixture of the bacterial cells with the fennel bulbs was exposed to $6 \mathrm{~mL}$ simulated saliva fluid (KCl [89.6 g/L]; KSCN [20 g/L]; $\mathrm{NaH}_{2} \mathrm{PO}_{4}[88.8 \mathrm{~g} / \mathrm{L}]$; $\mathrm{Na}_{2} \mathrm{SO}_{4}[57 \mathrm{~g} / \mathrm{L}] ; \mathrm{NaCl}[175.3 \mathrm{~g} / \mathrm{L}] ; \mathrm{NaHCO}_{3}[84.7 \mathrm{~g} / \mathrm{L}] ;$ urea [25 g/L]; $290 \mathrm{mg}$ of $\alpha$-amylase; $15 \mathrm{mg}$ of uric acid; $25 \mathrm{mg}$ mucin, $\mathrm{pH} 6.8 \pm 0.2$ ) for $5 \mathrm{~min}, 37^{\circ} \mathrm{C}, 60 \mathrm{rpm}$. After $5 \mathrm{~min}$ the artificial 
gastric medium $\left(1.884 \mathrm{~mL} \mathrm{NaCl}[175.3 \mathrm{~g} / \mathrm{L}] ; 0.36 \mathrm{~mL} \mathrm{NaH}_{2} \mathrm{PO}_{4}\right.$ $[88.8 \mathrm{~g} / \mathrm{L}] ; 1.104 \mathrm{~mL} \mathrm{KCl}[89.6 \mathrm{~g} / \mathrm{L}] ; 2.16 \mathrm{~mL} \mathrm{CaCl} \cdot 2 \mathrm{H}_{2} \mathrm{O}$ [22.2 g/L]; $1.2 \mathrm{~mL} \mathrm{NH}_{4} \mathrm{Cl}[30.6 \mathrm{~g} / \mathrm{L}] ; 0.09 \mathrm{~mL} \mathrm{HCl} 37 \%$ [w/w]; $1.2 \mathrm{~mL}$ glucose $[65 \mathrm{~g} / \mathrm{L}] ; 1.2 \mathrm{~mL}$ glucuronic acid $[2 \mathrm{~g} / \mathrm{L}] ; 0.408 \mathrm{~mL}$ urea $[25 \mathrm{~g} / \mathrm{L}] ; 1.2 \mathrm{~mL}$ glucosamine hydrochloride $[33 \mathrm{~g} / \mathrm{L}] ; 0.12 \mathrm{~g}$ bovine serum albumin; $0.3 \mathrm{~g}$ pepsin; $30 \mathrm{~mL}$ mucin [12 g/L], $\mathrm{pH}$ 2.5) was added and incubated for $2 \mathrm{~h}$, at $37^{\circ} \mathrm{C}$, with slight agitation $(60 \mathrm{rpm})$, followed by mixing an artificial intestinal fluid ( $\mathrm{pH}$ 6.5) to the gastric fluid with slight shaking for $2 \mathrm{~h}$ at $37^{\circ} \mathrm{C}, 60 \mathrm{rpm}$. The intestinal fluid was made by adding $2.4 \mathrm{~mL} \mathrm{NaCl}(175.3 \mathrm{~g} / \mathrm{L}) ; 2.4 \mathrm{~mL} \mathrm{NaHCO}{ }_{3}(84.7 \mathrm{~g} / \mathrm{L}) ; 0.6 \mathrm{~mL}$ $\mathrm{KH}_{2} \mathrm{PO}_{4}(8 \mathrm{~g} / \mathrm{L}) ; 0.378 \mathrm{~mL} \mathrm{KCl}(89.6 \mathrm{~g} / \mathrm{L}) ; 0.6 \mathrm{~mL} \mathrm{MgCl}_{2}(5 \mathrm{~g} / \mathrm{L})$; $0.0108 \mathrm{~mL} \mathrm{HCl} 37 \%(\mathrm{w} / \mathrm{w}) ; 0.24 \mathrm{~mL}$ urea $(25 \mathrm{~g} / \mathrm{L}) ; 0.54 \mathrm{~mL} \mathrm{CaCl}_{2}$, $2 \mathrm{H}_{2} \mathrm{O}(22.2 \mathrm{~g} / \mathrm{L}) ; 0.06 \mathrm{~g}$ BSA; $0.54 \mathrm{~g}$ pancreatin; $0.09 \mathrm{~g}$ lipase and bile fluid is composed of $1.2 \mathrm{~mL} \mathrm{NaCl}(175.3 \mathrm{~g} / \mathrm{L}) ; \mathrm{NaHCO}_{3}$ $(84.7 \mathrm{~g} / \mathrm{L}) ; 0.168 \mathrm{~mL} \mathrm{KCl}(89.6 \mathrm{~g} / \mathrm{L}) ; 0.006 \mathrm{~mL} \mathrm{HCl} \mathrm{37 \%} \mathrm{(w/w);}$ $0.4 \mathrm{~mL}$ urea $(25 \mathrm{~g} / \mathrm{L}) ; 0.4 \mathrm{~mL} \mathrm{CaCl}, 2 \mathrm{H}_{2} \mathrm{O}(22.2 \mathrm{~g} / \mathrm{L}) ; 0.072 \mathrm{~g}$ BSA; $1.2 \mathrm{~g}$ bile ( $0.6 \mathrm{~g}$ porcine bile, $0.6 \mathrm{~g}$ bovine bile). As control, a combined suspension of the three E. coli strains was used. The bacterial suspension was centrifuged $\left(3124 \mathrm{xg}, 5 \mathrm{~min}, 4^{\circ} \mathrm{C}\right)$ and exposed to the in vitro gastrointestinal system as described above. The viability of the bacterial cells was determined by the drop technique using TSA medium. Three biological replicates were tested and the viability determinations were performed in triplicate. The final $\mathrm{pH}$ value after the addition of the gastric fluid was 2.1 and after the addition of the intestinal fluid the $\mathrm{pH}$ value was 6.7.
For antioxidant activity, fresh sweet fennel bulbs Latina"(BL) and "Doux de Florence (BDF) Zn treated and non-treated ones were harvested in the spring 2014. The bulbs were washed thoroughly with sterile distilled water then stored at $-80{ }^{\circ} \mathrm{C}$ for ultimate assays. About $10 \mathrm{~g}$ of samples were submitted independently to the applied in vitro digestion process starting from mouth, to stomach and small intestine using the same conditions as aforementioned.

\subsection{Statistical analysis}

Statistical analysis was performed with the Statistical Package for the Social Sciences (SPSS) 23.0 software (SPSS Inc., Chicago, IL, USA). Results were examined by using one-way analysis of variance (ANOVA) followed by Tukey's multiple comparisons. The level of significance was set at $p<0.05$. Correlations were achieved by Spearman's correlation coefficient $(\mathrm{r})$ at a significance level of $95 \%$ or $99 \%$.

\section{Results and discussion}

\subsection{Total phenol and flavonoid contents}

Polyphenolic contents of non-treated and $\mathrm{Zn}$ treated bulbs were estimated in respect of digestion time, as shown in the Figures $1 \mathrm{a}$ and $1 \mathrm{~b}$.

Before digestion (time 0 ), in both varieties of fennel bulbs, those supplemented with $\mathrm{Zn}$ presented higher amounts of total (a)

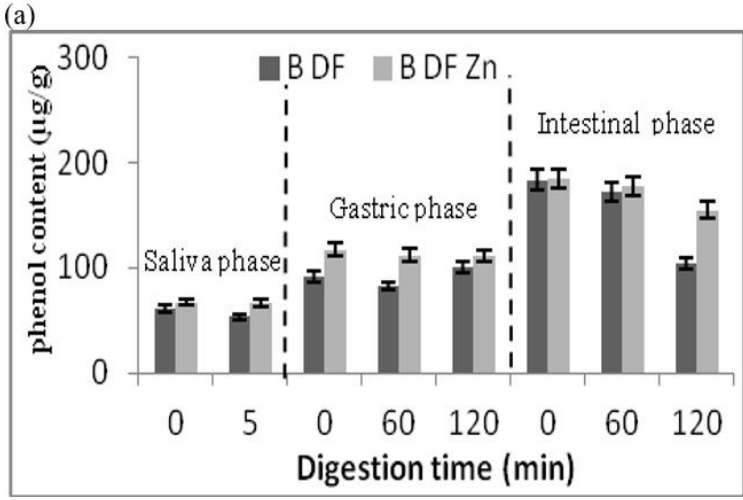

(b)

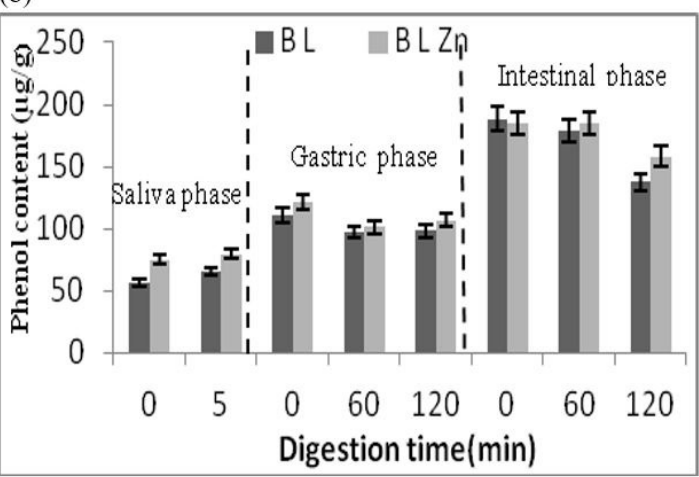

(d)

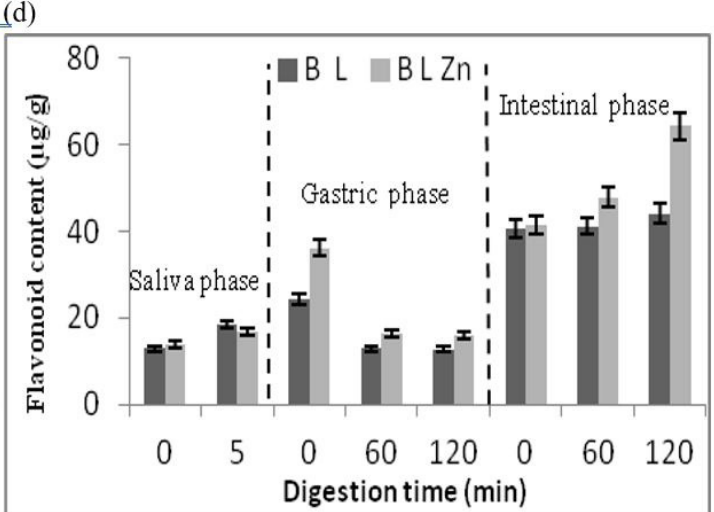

Figure 1. Total phenol $(\mathrm{a}, \mathrm{b})$ and total flavonoid $(\mathrm{c}, \mathrm{d})$ contents $(\mu \mathrm{g} / \mathrm{g})$ in the simulated gastrointestinal fluids in the presence of fennel bulbs 'Doux Florence' with no Zn treatment (B DF) and with Zn treatment (B DF Zn), fennel bulbs 'Latina' with no Zn treatment (B L) and with Zn treatment (B L Zn). 
phenols that was generally kept over the simulated digestion (Figure 1a and Figure 1b). The highest amounts of phenols in the samples supplemented with $\mathrm{Zn}$ disagree with those already published by this team, in which $\mathrm{Zn}$ was responsible for lower accumulation of phenols in the aerial parts of both varieties (Majdoub et al., 2017). Fennel bulb 'Latina' had a higher concentration of total phenols than the 'Doux de Florence' variety. The same had already been observed but for the aerial parts (Majdoub et al., 2017).

The simulated gastrointestinal (GI) in vitro digestion affected the polyphenol content in both varieties (Figure 1a and Figure 1b). In both bulb varieties, the amounts of phenols increased in the gastric phase as well as in the intestinal phase, where they reached the highest values. The polyphenols are associated with various other types of molecules (carbohydrates, organic acids, amino acids, lipids, among other molecules) in the form of esters, glycosides, or polymers. In addition, the distribution of such secondary metabolites is not the same in all parts of the food (Bhatt \& Patel, 2013; Manach et al., 2004). The quantitative evolution of polyphenols in simulated GI in vitro digestion has been studied and the results indicate that they can be dependent on the vegetable or fruit. For example, the polyphenol content has been described as decreasing along the simulated digestion in the case of pomegranate juice, apple, cherries or red cabbage (Bouayed et al., 2012; Fazzari et al., 2008); or increasing in the persimmon, broccoli, cashews, amaranth, wine and juices (Chandrasekara \& Shahidi, 2011; Martínez-Las-Heras et al., 2017; Pazinatto et al., 2013; Wootton-Beard et al., 2011). He et al. (2017) studied the evolution of phenols' contents along the simulated digestive process of 22 fruit juices and they reported that, with the exception of one sample, an increase of polyphenol content was observed during in vitro digestion, being Punica granatum that presented the most elevated release of polyphenols (about 3-fold).

The evolution of flavonoids' contents in the simulated gastrointestinal fluids in the presence of both varieties of fennel bulbs supplemented or not with $\mathrm{Zn}$ is depicted in Figure $1 \mathrm{c}$ and Figure 1d. As reported for total phenols, in almost all cases, those samples growing in a system supplemented with Zn presented higher concentrations of flavonoids. The concentration of flavonoids increased but only in the intestinal phase. Such was also observed for total phenols, nevertheless in the gastric phase the amounts did not increase in contrast to the results observed for total phenols (Figure 1a and Figure 1b). After ingestion, the phenols including flavonoids and/or their derivatives present in foods are gradually released from the food matrix and undergo alterations due to $\mathrm{pH}$ changes and enzyme action which may influence their absorption and biological activities (Thomas-Valdés et al., 2018). Our results may suggest that the amounts of flavonoids are not significantly influenced by the gastric $\mathrm{pH}$ in contrast to the phenols' content that underwent an increase in the gastric phase, although much more pronounced in the intestinal phase. According to Martínez-Las-Heras et al. (2017) who also found a significant increase of flavonoids in the intestinal phase of persimmon leaf infusion and fruit, such patterns may be explained by the key role of the intestinal enzymes and bile salts to catalyze the release of phenolics bound to the matrix as well as to the additional time of digestion.

\subsection{Antioxidant and anti-inflammatory activities}

The capacity for scavenging ABTS free radicals (Figures $2 a$ and $2 b$ ) by fluids with bulbs of both varieties of non-treated and $\mathrm{Zn}$ treated-fennel was higher in the intestinal phase. This trend coincided with the highest release of phenols, and particularly flavonoids.

Such is easily confirmed through the correlations made between those secondary compounds and the capacity for scavenging ABTS free radicals: correlation coefficient was higher between the content of flavonoids and the capacity for scavenging ABTS free radicals $(0.769 ; p<0.01))$ than in the correlation between the content of phenols and the capacity for scavenging ABTS free radicals $(0.615 ; p<0.01)$. The enhancement of the antioxidant activity after digestion was also previously reported for other vegetable juices and fruits (Cilla et al., 2011; He et al., 2017; Wootton-Beard et al., 2011), in contrast to other studies in which a decrease was reported respectively in Chilean white strawberry, wild currants or apple bagasse flour (Burgos-Edwards et al., 2017; Gullon et al., 2015; Thomas-Valdés et al., 2018).

The capacity for preventing lipid peroxidation was worst after in vitro digestion, particularly in the intestinal phase, in

(a)



(b)



Figure 2. ABTS scavenging activity (\%) of fluids with fennel bulb 'Doux Florence' with no Zn treatment (B DF) and with Zn treatment (B DF Zn) (a), and fennel bulb 'Latina' with no Zn treatment (B L) and with $\mathrm{Zn}$ treatment (B L Zn) (b) subjected to a simulated gastrointestinal digestion. 
which the levels of malondialdehyde (MDA) were remarkably higher than in the remaining phases (Figure $3 a$ and Figure $3 b$ ). MDA is a known biomarker for lipid peroxidation in which the lipids are the major targets of oxidizing agents and their oxidation results in short-chain aldehyde or carboxy derivatives, 4-hydroxynonenal (HNE) and malondialdehyde (MDA) (García Fillería \& Tironi, 2017). There is a positive correlation between the accumulation of MDA and the phenols and flavonoids. The results obtained in the present work may indicate that the highest amounts of phenols and flavonoids in the intestinal phase are positive in what concerns the capacity for scavenging some type of free radicals (i. e. ABTS) but these have a negative role in the prevention of lipid peroxidation, leading to the accumulation of MDA. In addition, the levels of this oxidation biomarker are significantly higher in Zn-treated bulbs of both varieties (Figures 3a, 3b).

Such results might be unexpected because $\mathrm{Zn}$ is considered to possess antioxidant property, since it works as a co-factor of some antioxidant defense enzymes (Marreiro et al., 2017). However, Ajina et al. (2017) reported that Zn provided to infertile men with asthenozoospermia and asthenoteratozoospermia did not prevent sperm lipid peroxidation or more recently, some authors (Lee, 2018; Marichali et al., 2016) described that an excess of Zn may cause oxidative stress evidenced by increased lipid peroxidation products (MDA) due to its pro-oxidant activity leading to cellular death.
The biosynthesis of leukotrienes is catalyzed by lipoxygenase through the oxidation of arachidonic acid or linoleic acid. During this process there is an introduction of diatomic oxygen (oxidation) giving rise to a hydroperoxy derivative of the fatty acid. The biosynthesis of those eicosanoids leads to the development of several inflammatory diseases (Rackova et al., 2007). The inhibition of this enzyme prevents inflammatory and oxidation processes (Smith\& Murphy, 2002).

The capacity for inhibiting the lipoxygenase activity is depicted in Figure $4 \mathrm{a}$ and Figure $4 \mathrm{~b}$, presented as $\mathrm{IC}_{50}$ values $(\mu \mathrm{g} / \mathrm{mL})$. As lower $\mathrm{IC}_{50}$ values as better is the activity. At time 0 , and in both fennel varieties, the presence of $\mathrm{Zn}$ enhanced the capacity for inhibiting the lipoxygenase, since the $\mathrm{IC}_{50}$ values were significantly lower than those samples without any supplementation of $\mathrm{Zn}$. This trend was maintained along the in vitro digestion process, with very few exceptions (Figure $4 \mathrm{a}$ and Figure $4 \mathrm{~b}$ ) that occurred particularly in the gastric phase (time $120 \mathrm{~min}$ in both varieties and time $60 \mathrm{~min}$ in the variety 'Latina'). The highest potency of the inhibition of lipoxygenase activity after digestion was also previously reported for coffee, ginger and cardamom extracts (Durak et al., 2015, 2017).

\section{Antimicrobial activity}

The survival of the of E. coli cells in the presence of the fennel bulbs ('Doux de Florence' (DF) and 'Latina' (L) grown in the absence of $\mathrm{Zn}$ or under $\mathrm{Zn}$ supplementation) was challenged

(a)

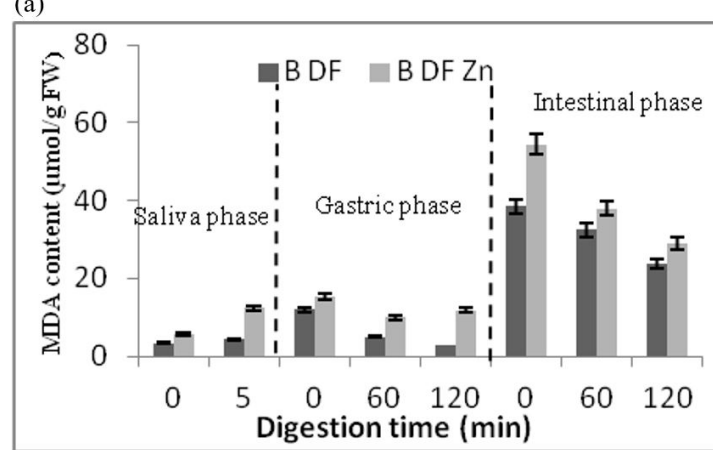

(b)

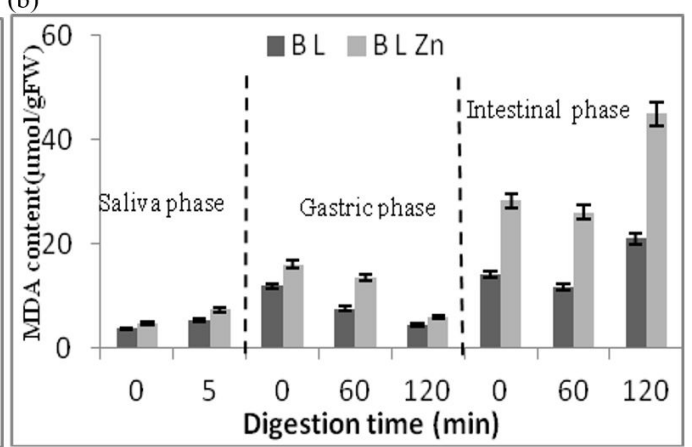

Figure 3. MDA content ( $\mu \mathrm{mol} / \mathrm{g} \mathrm{FW}$ ) in fluids with fennel bulb 'Doux Florence' with no Zn treatment (B DF) and with Zn treatment (B DF Zn) (a), and fennel bulb 'Latina' with no Zn treatment (B L) and with Zn treatment (B L Zn) (b) subjected to a simulated gastrointestinal digestion.
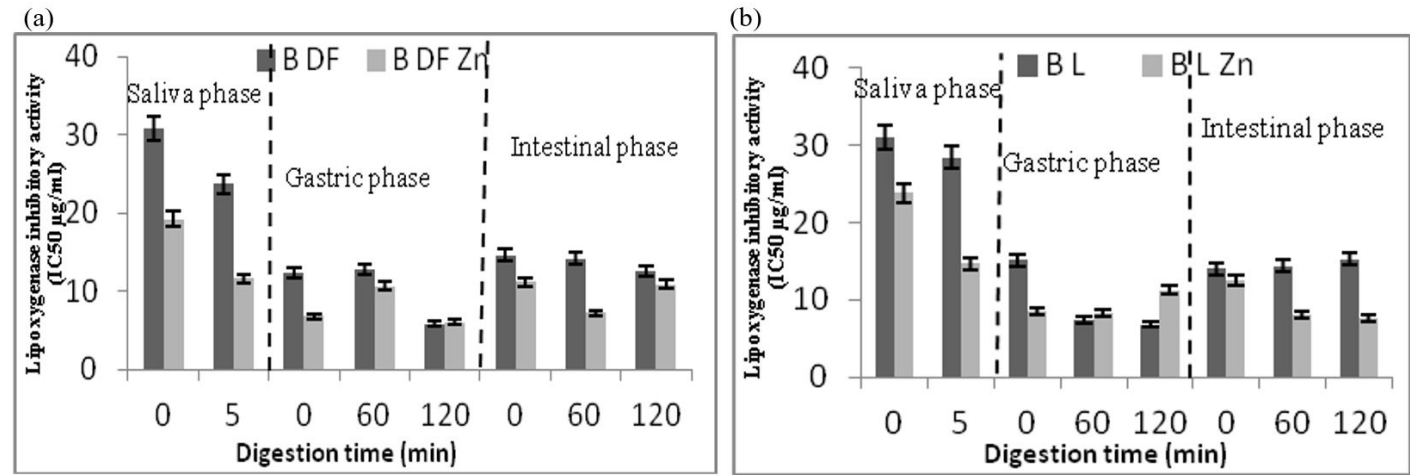

Figure 4. Lipoxygenase inhibitory activity ( $\mu \mathrm{g} / \mathrm{mL}$ bulb juice) of fluids with fennel bulb 'Doux Florence' with no Zn treatment ( B DF) and with Zn treatment (B DF Zn) (a), and fennel bulb 'Latina' with no Zn treatment ( B L) and with Zn treatment (B L Zn) (b) subjected to a simulated gastrointestinal digestion. 

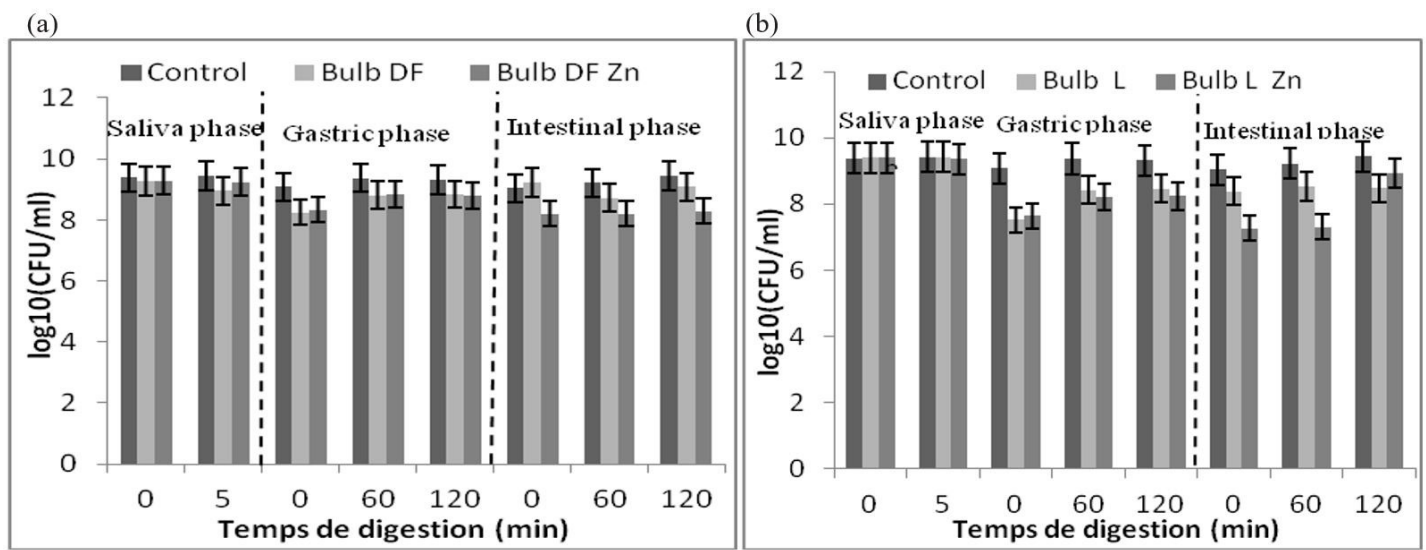

Figure 5. Survival of E.coli in the presence of with fennel bulb 'Doux Florence' with no Zn treatment (B DF) and with Zn treatment (B DF Zn) (a), and fennel bulb 'Latina' with no Zn treatment (B L) and with Zn treatment (B L Zn) (b) during the exposure to saliva, gastric and intestinal fluid. Data represent the mean of three replicates. Error bars represent the standard deviation.

with simulated gastrointestinal fluids and the results showed that the combined E. coli strains were able to overcome the exposure to the gastrointestinal synthetic fluids (Figure $5 \mathrm{a}$ and Figure 5b).

The E. coli cells challenged with synthetic saliva in the 'Doux de Florence' bulb (DF) showing a significant reduction $(p<0.05)$ after $5 \mathrm{~min}$ in comparison to control and cells in DF with $\mathrm{Zn}$ supplementation (DF $\mathrm{Zn}$ ). After the addition of the gastric fluid the E. coli cells either in the DF bulb with no Zn or under $\mathrm{Zn}$ supplementation experienced a significant reduction $(p<0.05)$ in comparison to control (Figure 5a). The addition of the intestinal fluid impaired more significantly $(p<0.05)$ the E. coli cells in the bulb DF Zn in comparison to control and E. coli cells in the bulb DF (Figure 5a). However, after $2 \mathrm{~h}$ the E. coli cells from DF Zn were able to recover and achieve similar numbers to $E$. coli cells recovered from DF bulb. It is important to stress that the viability of control $E$. coli cells remained the same throughout the gastrointestinal challenge (Figure 5a). The results of the experiment with the 'Latina' (L) bulb grown in the absence of $\mathrm{Zn}$ (Bulb L) or under $\mathrm{Zn}$ supplementation (Bulb L Zn) showed that the E. coli cells retain $100 \%$ survival rate after the addition of the synthetic saliva (Figure $5 b$ ). However, the addition of the gastric fluid impaired the viability of the E. coli cells recovered from the bulbs $\mathrm{L}$ and $\mathrm{L} \mathrm{Zn}$ in comparison with the control E. coli cells over the $2 \mathrm{~h}$ of the gastric challenge $(p<0.05)$. The exposure of $E$. coli cells to the intestinal fluids caused a significant reduction of the bacterial cells from both bulbs, L and L Zn, but particularly to the viability of $E$. coli cells retrieved from the bulb L Zn ( $<0.05)$. However, after $2 \mathrm{~h}$, the viability of $E$. coli cells from the bulb L Zn exceed $(p<0.05)$ the viability of the E. coli cells from the bulb L (Figure 5b). Also, in the experiment with the L bulbs, the control E. coli cells were able to overcome the gastrointestinal challenge (Figure 5b).

Overall the viability of $E$. coli cells was impaired by both fennel bulbs when exposed either to the gastric or intestinal fluids but mostly by exposure to the intestinal fluid in the bulbs that were under $\mathrm{Zn}$ supplementation (Figure 5a, Figure $5 b$ ). The contamination of fresh produce and ready-to-eat salads with E. coli is well documented (Weller et al., 2017; Mikhail et al.,
2018) and represents a health risk to consumers, in particular to immunocompromised individuals that in virtue of their health status are obliged to consume healthier foods. The fact that the survival of $E$. coli cells was impaired more significantly at the intestinal phase, particularly in the presence of bulbs supplemented with $\mathrm{Zn}$ can be explained by the higher total phenol content and the higher concentration of flavonoids at the intestinal phase, especially for Zn supplemented bulbs. Nevertheless, E. coli cells were able to recover their survival after $2 \mathrm{~h}$ of the intestinal challenge even in the presence of the highest quantity of flavonoids. This behavior of the E. coli cells is characteristic of an adaptation response to injury agents (Begley \& Hill, 2015; Faleiro, 2011). Our results reinforce the potential hazards of consuming contaminated fresh produce and the need for good hygienic practices.

\section{Acknowledgements}

Authors acknowledge this research was partially funded by Fundação para a Ciência e a Tecnologia (FCT), under the projects UID/BIA/04325/2013 - MEDTBIO, and UID/BIM/04773/2013 CBMR.

\section{References}

Ajina, T., Sallem, A., Haouas, Z., \& Mehdi, M. (2017). Total antioxidant status and lipid peroxidation with and without in vitro zinc supplementation in infertile men. Andrologia, 49(7), e12703. http:// dx.doi.org/10.1111/and.12703. PMid:27686342.

Babich, H., \& Stotzky, G. (1978). Toxicity of zinc to fungi, bacteria, and coliphages: influence of chloride ions. Applied and Environmental Microbiology, 36(6), 906-914. PMid:736544.

Begley, M., \& Hill, C. (2015). Stress adaptation in foodborne pathogens. Annual Review of Food Science and Technology, 6(1), 191-210. http:// dx.doi.org/10.1146/annurev-food-030713-092350. PMid:25665171.

Bhatt, A., \& Patel, V. (2013). Antioxidant activity of garlic using conventional extraction and in vitro gastrointestinal digestion. Free Radicals and Antioxidants, 3(1), 30-34. http://dx.doi.org/10.1016/j. fra.2013.03.003.

Bouayed, J., Deußer, H., Hoffmann, L., \& Bohn, T. (2012). Bioaccessible and dialyzable polyphenols in selected apple varieties following in 
vitro digestion vs. their native patterns. Food Chemistry, 131(4), 1466-1472. http://dx.doi.org/10.1016/j.foodchem.2011.10.030.

Burgos-Edwards, A., Jiménez-Aspee, F., Thomas-Valdés, S., SchmedaHirschmann, G., \& Theoduloz, C. (2017). Qualitative and quantitative changes in polyphenol composition and bioactivity of Ribes magellanicum and $R$. punctatum after in vitro gastrointestinal digestion. Food Chemistry, 237, 1073-1082. http://dx.doi.org/10.1016/j. foodchem.2017.06.060. PMid:28763953.

Chandrasekara, N., \& Shahidi, F. (2011). Antioxidative potential of cashew phenolics in food and biological model systems as affected by roasting. Food Chemistry, 129(4), 1388-1396. http://dx.doi. org/10.1016/j.foodchem.2011.05.075.

Chowdhury, M. I., Hasan, M., Islam, M. S., Sarwar, M., Amin, M. N., Uddin, S. M. N., Rahaman, M. Z., Banik, S., Hussain, M. S., Yokota, K., \& Hasnat, A. (2017). Elevated serum MDA and depleted non-enzymatic antioxidants, macro-minerals and trace elements are associated with bipolar disorder. Journal of Trace Elements in Medicine and Biology, 39, 162-168. http://dx.doi.org/10.1016/j. jtemb.2016.09.012. PMid:27908410.

Cilla, A., Perales, S., Lagarda, M. J., Barberá, R., Clemente, G., \& Farré, R. (2011). Influence of storage and in vitro gastrointestinal digestion on total antioxidant capacity of fruit beverages. Journal of Food Composition and Analysis, 24(1), 87-94. http://dx.doi.org/10.1016/j. jfca.2010.03.029.

Durak, A., Gawlik-Dziki, U., \& Kowlska, I. (2015). Coffee with ginger - interactions of biologically active phytochemicals in the model system. Food Chemistry, 166(1), 261-269. http://dx.doi.org/10.1016/j. foodchem.2014.06.075. PMid:25053054.

Durak, A., Gawlik-Dziki, U., \& Kowalska, I. (2017). Evaluation of interactions between coffee and cardamom, their type, and strength in relation to interactions in a model system. CYTA: Journal of Food, 15(2), 266-276. http://dx.doi.org/10.1080/19476337.2016.1247298.

El-Guendouz, S., Aazza, S., Lyoussi, B., Antunes, M. D., Faleiro, M. L., \& Miguel, M. G. (2016). Anti-acetylcholinesterase, antidiabetic, anti-inflammatory, antityrosinase and antixanthine oxidase activities of Moroccan propolis. International Journal of Food Science \& Technology, 51(8), 1762-1773. http://dx.doi.org/10.1111/ijfs.13133.

Faleiro, M. L. (2011). The mode of antibacterial action of essential oils. In A. Méndez-Vilas (Ed.), Science against microbial pathogens: communicating current research and technological advances (Microbiology Book Series). Badajoz: Formatex Research Center.

Fazzari, M., Fukumoto, L., Mazza, G., Livrea, M. A., Tesoriere, L., \& Marco, L. D. (2008). In vitro bioavailability of phenolic compounds from five cultivars of frozen sweet cherries (Prunus avium L.). Journal of Agricultural and Food Chemistry, 56(10), 3561-3568. http://dx.doi. org/10.1021/jf073506a. PMid:18459792.

García Fillería, S. F., \& Tironi, V. A. (2017). Prevention of in vitro oxidation of low density lipoproteins (LDL) by amaranth peptides released by gastrointestinal digestion. Journal of Functional Foods, 34, 197-206. http://dx.doi.org/10.1016/j.jff.2017.04.032.

Gullon, B., Pintado, M. E., Barber, X., Fernández-López, J., Pérez-Álvarez, J. A., \& Viuda-Martos, M. (2015). Bioaccessibility, changes in the antioxidant potential and colonic fermentation of date pits and apple bagasse flours obtained from co-products during simulated in vitro gastrointestinal digestion. Food Research International, 78, 169-176. http://dx.doi.org/10.1016/j.foodres.2015.10.021. PMid:28433278.

He, M., Zeng, J., Zhai, L., Liu, Y., Wu, H., Zhang, R., Li, Z., \& Xia, E. (2017). Effect of in vitro simulated gastrointestinal digestion on polyphenol and polysaccharide content and their biological activities among 22 fruit juices. Food Research International, 102, 156-162. http://dx.doi.org/10.1016/j.foodres.2017.10.001. PMid:29195935.
Lee, S. R. (2018). Critical role of zinc as either an antioxidant or a prooxidant in cellular systems. Oxidative Medicine and Cellular Longevity, 2018, 9156285. http://dx.doi.org/10.1155/2018/9156285. PMid:29743987.

Majdoub, N., El-Guendouz, S., Rezgui, M., Carlier, J., Costa, C., Kaab, L. B. B., \& Miguel, M. G. (2017). Growth, photosynthetic pigments, phenolic content and biological activities of Foeniculum vulgare Mill., Anethum graveolens L. and Pimpinella anisum L. (Apiaceae) in response to zinc. Industrial Crops and Products, 109, 627-636. http://dx.doi.org/10.1016/j.indcrop.2017.09.012.

Manach, C., Scalbert, A., Morand, C., Rémésy, C., \& Jiménez, L. (2004). Polyphenols: Food sources and bioavailability. The American Journal of Clinical Nutrition, 79(5), 727-747. http://dx.doi.org/10.1093/ ajcn/79.5.727. PMid:15113710.

Marichali, A., Dallali, S., Ouerghemmi, S., Sebei, H., Casabianca, H., \& Hosni, K. (2016). Responses of Nigella sativa L. to zinc excess: focus on germination, growth, yield and yield components, lipid and terpene metabolism, and total phenolics and antioxidant activities. Journal of Agricultural and Food Chemistry, 64(8), 1664-1675. http:// dx.doi.org/10.1021/acs.jafc.6b00274. PMid:26853463.

Marreiro, D., Cruz, K., Morais, J., Beserra, J., Severo, J., \& Oliveira, A. (2017). Zinc and oxidative stress: current mechanisms. Antioxidants, 6(2), 24. http://dx.doi.org/10.3390/antiox6020024. PMid:28353636.

Martínez-Las-Heras, R., Pinazo, A., Heredia, A., \& Andrés, A. (2017). Evaluation studies of persimmon plant (Diospyros kaki) for physiological benefits and bioaccessibility of antioxidants by in vitro simulated gastrointestinal digestion. Food Chemistry, 214, 478-485. http://dx.doi.org/10.1016/j.foodchem.2016.07.104. PMid:27507501.

Melo, J., Schrama, D., Hussey, S., Andrew, P. W., \& Faleiro, M. L. (2013). Listeria monocytogenes dairy isolates show a different proteome response to sequential exposure to gastric and intestinal fluids. International Journal of Food Microbiology, 163(2-3), 51-63. http:// dx.doi.org/10.1016/j.ijfoodmicro.2013.03.001. PMid:23558187.

Mikhail, A. F. W., Jenkins, C., Dallman, T. J., Inns, T., Douglas, A., Martín, A. I. C., Fox, A., Cleary, P., Elson, R., \& Hawker, J. (2018). An outbreak of Shiga toxin-producing Escherichia coli O157:H7 associated with contaminated salad leaves: epidemiological, genomic and food trace back investigations. Epidemiology and Infection, 146(2), 187-196. http://dx.doi.org/10.1017/S0950268817002874. PMid:29248018.

Murugan, R., Chandran, R., \& Parimelazhagan, T. (2016). Effect of in vitro simulated gastrointestinal digestion of Phoenix loureirii on polyphenolics, antioxidant and acetylcholinesterase inhibitory activities. Lebensmittel-Wissenschaft + Technologie, 74, 363-370. http://dx.doi.org/10.1016/j.lwt.2016.07.075.

Pavan, V., Sancho, R. A. S., \& Pastore, G. M. (2014). The effect of in vitro digestion on the antioxidant activity of fruit extracts (Carica papaya, Artocarpus heterophillus and Annona marcgravii). Lebensmittel-Wissenschaft + Technologie, 59(2), 1247-1251. http:// dx.doi.org/10.1016/j.lwt.2014.05.040.

Pazinatto, C., Malta, L. G., Pastore, G. M., \& Maria, F. No. (2013). Antioxidant capacity of amaranth products: eefects of thermal and enzymatic treatments. Food Science and Technology, 33(3), 485-493. http://dx.doi.org/10.1590/S0101-20612013005000076.

Pinto, J., Spínola, V., Llorent-Martínez, E. J., Fernández-de Córdova, M. L., Molina-García, L., \& Castilho, P. C. (2017). Polyphenolic profile and antioxidant activities of Madeiran elderberry (Sambucus lanceolata) as affected by simulated in vitro digestion. Food Research International, 100(3), 404-410. http://dx.doi.org/10.1016/j. foodres.2017.03.044. PMid:28964363. 
Rackova, L., Oblozinsky, M., Kostalova, G., Kettmann, V., \& Bezakova, L. (2007). Free radical scavenging activity and lipoxygenase inhibition of Mahonia aquifolium extract and isoquinoline alkaloids. Journal of Inflammation, 4(1), 15. http://dx.doi.org/10.1186/1476-9255-415. PMid:17634120.

Rawson, A., Hossain, M. B., Patras, A., Tuohy, M., \& Brunton, N. (2013). Effect of boiling and roasting on the polyacetylene and polyphenol content of fennel (Foeniculum vulgare) bulb. Food Research International, 50(2), 513-518. http://dx.doi.org/10.1016/j. foodres.2011.01.009.

Rout, G., \& Das, P. (2003). Effect of metal toxicity on plant growth and metabolism: I. Zinc. Agronomie, 23(1), 3-11. http://dx.doi. org/10.1051/agro:2002073.

Senatore, F., Oliviero, F., Scandolera, E., Taglialatela-Scafati, O., Roscigno, G., Zaccardelli, M., \& de Falco, E. (2013). Chemical composition: antimicrobial and antioxidant activities of anethole-rich oil from leaves of selected varieties of fennel. Fitoterapia, 90, 214-219. http:// dx.doi.org/10.1016/j.fitote.2013.07.021. PMid:23933237.

Smith, W. L., \& Murphy, R. C. (2002). The eicosanoids: cyclooxygenase, lipoxygenase, and epoxygenase pathways, In D. E. Vance \& J. E. Vance (Eds.), Biochemistry of lipids, lipoproteins and membranes (pp. 341-372). New York: Elsevier. http://dx.doi.org/10.1016/S01677306(02)36015-0.
Thomas-Valdés, S., Theoduloz, C., Jiménez-Aspee, F., Burgos-Edwards, A., \& Schmeda-Hirschmann, G. (2018). Changes in polyphenol composition and bioactivity of the native Chilean white strawberry (Fragaria chiloensis spp. chiloensis f. chiloensis) after in vitro gastrointestinal digestion. Food Research International, 105, 10-18. http://dx.doi.org/10.1016/j.foodres.2017.10.074. PMid:29433189.

Wang, C., Li, B., Wang, B., \& Xie, N. (2015). Degradation and antioxidant activities of peptides and zinc-peptide complexes during in vitro gastrointestinal digestion. Food Chemistry, 173, 733-740. http:// dx.doi.org/10.1016/j.foodchem.2014.10.066. PMid:25466083.

Weller, D. L., Kovac, J., Kent, D. J., Roof, S., Tokman, J. I., Mudrak, E., Kowalcyk, B., Oryang, D., Aceituno, A., \& Wiedmann, M. (2017). Escherichia coli transfer from simulated wildlife feces to lettuce during foliar irrigation: a field study in the Northeastern United States. Food Microbiology, 68, 24-33. http://dx.doi.org/10.1016/j. fm.2017.06.009. PMid:28800822.

Wootton-Beard, P. C., Moran, A., \& Ryan, L. (2011). Stability of the total antioxidant capacity and total polyphenol content of 23 commercially available vegetable juices before and after in vitro digestion measured by FRAP, DPPH, ABTS and Folin-Ciocalteu methods. Food Research International, 44(1), 217-224. http://dx.doi. org/10.1016/j.foodres.2010.10.033. 